\title{
Pengaruh Metode Pembelajaran dan Gaya Belajar Siswa Terhadap Hasil Belajar IPS SMP
}

\section{The Effects of Instructional Method and The Learning Style on Social Studies Learning Outcome of The Students of Junior High Schools}

\author{
Azharotunnafi a,1, Muhsinatun Siasah M. ${ }^{\text {b,2 }}$ \\ a,b Program Pascasarjana, Universitas Negeri Yogyakarya \\ 1.azharotunnafi@gmail.com, ${ }^{2}$ muhsinsiasah@gmail.com
}

\begin{tabular}{ll}
\hline Informasi artikel & ABSTRAK \\
\hline Kata Kunci: & Penelitian ini bertujuan untuk mengungkapkan pengaruh: (1) metode \\
metode pembelajaran, & inquiry dan problem solving terhadap hasil belajar IPS; (2) metode \\
gaya belajar, hasil belajar & inquiry dan problem solving terhadap hasil belajar IPS pada siswa gaya \\
IPS & belajar auditorial; (3) metode inquiry dan problem solving terhadap \\
& hasil belajar IPS pada siswa gaya belajar visual; dan (4) interaksi \\
& metode pembelajaran dan gaya belajar terhadap hasil belajar IPS. \\
& Penelitian ini merupakan quasi experiment dengan desain faktorial $2 \times 2$. \\
& Populasi penelitian ini adalah seluruh siswa SMP Negeri di Kota \\
& Yogyakarta. Pengambilan sampel menggunakan multistage random \\
& Sampling dan terpilih SMP Negeri 2 Yogyakarta dan SMP Negeri 9 \\
& Yogyakarta. Validitas instrumen hasil belajar diukur dengan expert \\
& judgement dan reliabilitasnya dengan iteman. Validitas angket diukur \\
& dengan analisis faktor dan reliabilitasnya menggunakan Cronbach's \\
& Alpha. Normalitas data menggunakan Kolmogorov-Smirnov. \\
& Homogenitas data menggunakan Levene test. Uji hipotesis \\
menggunakan Analisis Varian $2 \times 2$. Hasil penelitian menunjukkan \\
bahwa: (1) terdapat pengaruh metode inquiry dan problem solving \\
terhadap hasil belajar IPS $(0,003<0,05) ;(2)$ tidak terdapat pengaruh \\
metode inquiry dan problem solving terhadap hasil belajar IPS pada \\
siswa gaya belajar auditorial $(0,815>0,05) ;(3)$ terdapat pengaruh \\
metode inquiry dan problem solving terhadap hasil belajar IPS pada \\
siswa gaya belajar visual $(0,001<0,05) ;$ dan (4) terdapat interaksi \\
pengaruh metode pembelajaran dan gaya belajar siswa terhadap hasil \\
belajar IPS $(0,001<0,05)$.
\end{tabular}

Keywords:

teaching method, learning style, social studies learning outcomet

\section{ABSTRACT}

This research aims to reveal the effect of: (1) the inquiry method and problem solving method on the social studies learning outcome; (2) the inquiry method and problem solving method on the social studies learning outcome of the students with auditory learning style; (3) the inquiry method and problem solving method on the social studies learning outcome of the students with visual learning style; and (4) the interaction of teaching method and students' learning style on the social studies learning outcome. This research was a quasi-experiment using the 2x2 factorial design. The study population was all students of state junior high schools in Yogyakarta. The sample was established using the multistage random sampling. It consisted of SMP Negeri 2 Yogyakarta and SMP Negeri 9 Yogyakarta. The validity of the assessment was measured by expert judgment and the realibility was measured by using the iteman. The validity of the questionnaire was measured by factor analysis and the realibility of the questionnaire was measured by Cronbach's Alpha. The data normality was tested by 
Kolmogorov-Smirnov. The data homogeneity was tested by levene test. The hypothesis testing was performed using the analysis of variance $2 \times 2$. The results of this research show that: (1) there is an effect of the inquiry method and problem solving method on the social studies learning outcome $(0.003<0.05)$; (2) there is no effect of the inquiry method and problem solving method on the social studies learning outcome of the students with auditory learning style (0.815 > 0.05); (3) there is an effect of the inquiry method and problem solving method on the social studies learning outcome of the students with visual learning style $(0.001<0.05)$; and (4) there is an interaction effect of teaching method and students' learning style on the social studies learning outcome $(0.001<0.05)$.

\section{Pendahuluan}

Pendidikan perlu didesain sedemikian rupa sehingga dapat menciptakan kondisi pembelajaran efektif dan efisien. Berdasarkan Peraturan Pemerintah pasal 19 No. 32 Tahun 2013 mengenai standar nasional pendidikan, bahwa

Proses pembelajaran pada satuan pendidikan diselenggarakan secara interaktif, inspiratif, menyenangkan, menantang, memotivasi peserta didik untuk berpartisipasi aktif, serta memberikan ruang yang cukup bagi prakarsa, kreativitas, dan kemandirian sesuai dengan bakat, minat, dan perkembagan fisik serta psikologis peserta didik.

Proses pembelajaran perlu melibatkan komponen-komponen yang disebutkan di atas agar efektivitas pembelajaran dapat tercapai. Proses pembelajaran harus diselenggarakan sedemikian rupa agar siswa mampu berpartisipasi aktif dan mandiri sesuai dengan bakat dan minat. Sehingga ketika siswa terjun langsung dalam masyarakat, maka siswa akan mampu bertindak untuk memecahkan permasalahan yang terjadi di masyarakat. Hal ini sejalan dengan tujuan IPS yaitu peserta didik dapat menjadi warga negara yang baik sehingga mampu menelaah dan memecahkan permasalahan sosial yang ada di masyarakat (Supardi, 2011, p.182).

Sesuai dengan visi pendidikan nasional menurut Undang-Undang Sisdiknas nomor 20 tahun 2003 yaitu pendidikan nasional berfungsi mengembangkan kemampuan dan membentuk watak serta peradaban bangsa yang bermartabat dalam rangka mencerdaskan kehidupan bangsa, mewujudkan sistem pendidikan sebagai pranata sosial yang kuat dan berwibawa untuk memberdayakan semua warga negara Indonesia agar berkembang menjadi manusia yang berkualitas sehingga mampu dan proaktif menjawab tantangan zaman yang selalu berubah.

Realita yang ada di masyarakat menunjukkan adanya berbagai permasalahan sosial dalam kehidupan sehari-hari, di antaranya banyak terjadi permasalahan sosial dan kriminalitas seperti perampokan, pencurian, pembunuhan, kekerasan, tawuran antarpelajar, bahkan sampai kasus korupsi yang ironisnya dilakukan oleh orang yang memiliki intelektualitas tinggi dan orangorang kalangan mengengah ke atas. Sehubungan dengan itu, maka pembelajaran yang dilakukan di kelas harus bersifat efektif. Pembelajaran dikatakan efektif apabila siswa dapat mencapai hasil belajar sesuai dengan tujuan pembelajaran yang diharapkan sebagaimana dirumuskan dalam standar kompetensi.

Seiring dengan perkembangan dunia pendidikan, kurikulum pembelajaran didesain sesuai dengan tingkat kebutuhan. Bahkan setiap sekolah sekarang ini telah diberikan wewenang untuk melaksanakan dan mengembangkan kurikulum sesuai dengan kebutuhan. Dahulu, sebelum teknologi dan komunikasi berkembang 
pesat, kegiatan pembelajaran yang dilakukan bersifat teacher centered atau terpusat pada guru. Guru menjadi sumber belajar utama. Metode pembelajaran yang digunakan adalah ceramah. Metode ceramah dahulu merupakan metode yang memang dapat membantu mencukupi kebutuhan belajar siswa. Ketika teknologi masih terbatas, dan sumber belajar terpaku pada guru, siswa mampu belajar hanya dengan mendengarkan informasi dari guru. Berbeda dengan sekarang, siswa cenderung cepat bosan hanya dengan mendengar apa yang disampaikan guru saja. Oleh karena itu, pembelajaran dirancang berorientasi pada siswa atau student centered. Dalam hal ini, siswa adalah pemeran utama dalam pembelajaran bukan sebagai objek pembelajaran. Peserta didik diarahkan untuk mendominasi kegiatan pembelajaran di kelas, termasuk mencari dan menggali ilmu pengetahuan dengan hasil temuan siswa. Seiring dengan berkembangnya teknologi informasi dan komunikasi, siswa dapat menemukan berbagai sumber belajar baik media cetak maupun online. Hal ini sesuai dengan pendapat Rodger \& Bybee (Flick \& Lederman, 2006, p.8)

Students come to learning situations with knowledge and explanations for their world. As students form their understanding, they link new information with the knowledge they bring to the learning experience. Therefore, it is important that curricula and teachers provide wellarticulated learning experiences that will help students make the connections between new concepts and the knowledge they already have.

Berdasarkan pendapat tersebut, pembelajaran dilakukan dengan siswa datang ke situasi belajar dengan pengetahuan dan penjelasan untuk dunia mereka. Sebagai siswa membentuk pemahaman siswa, menghubungkan informasi baru dengan pengetahuan yang mereka bawa ke pengalaman belajar. Oleh karena itu, penting bahwa kurikulum dan guru memberikan baik diartikulasikan pengalaman belajar yang akan membantu siswa membuat hubungan antara konsepkonsep baru dan pengetahuan yang dimiliki siswa. Perlu adanya penyamaan konsep pembelajaran dan pengalaman yang dimiliki siswa. Inilah yang disebut pembelajaran kontekstual, bersifat student center dan melibatkan pengalaman belajar siswa. Pembelajaran yang baik adalah pembelajaran yang dapat mencapai hasil yang sesuai dengan tujuan dan berstandar proses.

Ada beberapa tingkatan untuk menentukan ketercapaian kompetensi hasil belajar. Bloom (1956, p.18) menyatakan bahwa as the taxonomy is now organized, it contains six major classes: (1) knowledge; (2) comprehension; (3) application; (4) analysis; (5) syntesis; (6) evaluation. Pernyataan tersebut dapat diartikan bahwa tingkatan tersebut adalah pengetahuan, pemahaman, aplikasi, analisis, sintesis, dan evaluasi. Tingkatan tersebut adalah tingkatan paling rendah sampai tingkatan paling tinggi. Jika peserta peserta didik memiliki bisa memberikan kemampuan berpikir sampai tingkat analisis atau sintesis, maka pencapaian hasil belajarnya memuaskan.

Pentingnya Pemilihan Metode dalam Pembelajaran

Metode yang digunakan dalam pembelajaran dapat mempengaruhi hasil belajar. Hal ini dikarenakan metode merupakan hal penting yang harus direncanakan oleh guru dengan baik, agar implementasi pembelajaran dapat berjalan sesuai dengan standar proses dan tujuan seperti yang dijelaskan dalam Peraturan Pemerintah pasal 19 No. 32 Tahun 2013 mengenai standar nasional pendidikan.

Sejalan dengan pendapat Ismail, bahwa ada beberapa faktor yang dapat mempengaruhi efektivitas pembelajaran, baik yang berasal dari dalam maupun dari luar. Menurut Ismail (2008, p.31) faktor tersebut antara lain kualitas pengaturan 
unsur-unsur belajar dengan memperhatikan metode-metode pembelajaran dan efektivitas pembelajaran.

\section{Pendekatan Saintifik}

Pembelajaran akan berjalan secara efektif apabila diikuti dengan hal-hal yang mendukung, baik itu persiapan maupun proses. Metode merupakan salah satu aspek yang mempengaruhi keefektifan dalam pembelajaran. metode yang digunakan dalam penelitian ini mengacu pada pendekatan saintifik. Pendekatan saintifik yaitu pendekatan pembelajaran yang mengacu pada metode ilmiah.

Pendekatan saintifik menurut Hosman (2014, p.34) yaitu bahwa pendekatan saintifik meruoakan proses pembelajaran yang dirancang sedemikian rupa agar peserta didik secara aktif mengkonstruk konsep, hukum atau prinsip melalui tahapan-tahapan mengamati (untuk menidentifikasi menemukan masalah), merumuskan masalah, mengajukan atau merumuskan hipotesis, mengumpulkan data dengan berbagai teknik, menganalisis data, menarik kesimpulan dan mengkomunikasikan konsep, hukum atau prinsip yang ditemukan.

Metode yang dapat digunakan untuk melatih kemampuan berpikir kritis siswa adalah metode problem solving dan inquiry. Oleh karena itu, diharapkan dengan penerapan metode inquiry dan problem solving siswa mampu berpikir menemukan dan memecahkan masalah sehingga dapat diterapkan dalam kehidupan sehari-hari. Metode ini juga sesuai dengan prinsip pembelajaran saintifik yang berbasis pada metode ilmiah dalam pembelajaran.

\section{Metode Inquiry dan Problem Solving}

Metode inquiry dan problem solving merupakan metode yang menekankan pada pendekatan saintifik, karena dilihat dari langkah-langkahnya, kedua metode tersebut memiliki langkah yang menekankan pada pendekatan saintifik.
"Inquiry-based learning is a process where students are involved in their learning, formulate questions, investigate widely and then build new understandings, meanings and knowledge" (Branch \& Oberg, 2004, p.1). Jadi inquiry merupakan pembelajaran yang melibatkan siswa dalam melakukan investigasi lebih luas melalui pertanyaan-pertanyaan sehingga dapat membentuk pengetahuan. Menurut Kilbane \& Milman (2014, p.244), inquiry adalah

A process-oriented instructional model that aims to teach students the skill, knowledge, and dispositions required for thinking systematically to answer important questions. Through participation in the inquiry model, students also develop knowledge of academic content that includes understanding of facts, principles, and concepts within a meaningful context-the solving of a problem. The inquiry model is a engaging, active, and often collaborative.

Pendapat di atas dapat mengandung maksud bahwa inquiry merupakan metode yang berorientasi pada proses dan bertujuan mengajarkan keterampilan siswa, pengetahuan, kemampuan berpikir sistematis dalam menjawab pertanyaan. Siswa juga diajak untuk mengembangkan akademik yang meliputi pemahaman fakta, prinsip, dan pemecahan masalah. Metode inquiry merupakan metode yang menarik, aktif dan kolaboratif.

Menurut Burden \& Byrd (2011, p.153) "inquiry is an open-ended and creative way of seeking knowledge. One of the strengths of this approach is that both the lesson content and the process of investigation are taught at the same". Inquiry merupakan metode pembelajaran yang dapat mendorong siswa aktif. Lebih jelasnya, Wina (2006, p.196) menyatakan bahwa inquiry merupakan rangkaian kegiatan pembelajaran yang menekankan pada proses berpikir secara kritis dan analitis untuk mencari dan menemukan 
sendiri jawaban dari masalah atau tugas yang dipertanyakan.

Menurut Shoimin (2014, p.136) problem solving adalah suatu keterampilan yang meliputi kemampuan untuk mencari informasi, menganalisis situasi, dan mengidentifikasi masalah dengan tujuan untuk menghasilkan alternatif sehingga dapat mengambil suatu tindakan keputusan untuk mencapai sasaran. Model ini dapat menstimulus peserta didik dalam berpikir yang dimuali dari mencari data sampai menarik kesimpulan sehingga peserta didik dapat mengambil makna dari kegiatan pembelajaran.

Pendapat lain dinyatakan oleh Burden \& Byrd (2011, p.155) bahwa:

Problem solving involves the application of knowledge and skill to achieve certain goals. There are several components for ploblem solving skill (Slavin 2012). First, means-ends analysis is a problem, the current situation, and what needs to be done (the means) to reduce the difference between the two conditions. Second, creative problem solving involves cases for which the answers are not very clear or straightforward.

Menurut pendapat tersebut, problem solving melibatkan penerapan pengetahuan dan keterampilan untuk mencapai tujuan tertentu. Ada beberapa komponen untuk keterampilan problem solving. Pertama, keterampilan bagaimana cara menganalisis sebuah permasalahan untuk dikaji. Kedua, bagaimana merangkum hasil analisis untuk dicari solusinya.

\section{Metode Penelitian}

Jenis Penelitian

Jenis penelitian ini adalah quasi experiment (eksperimen semu) dengan desain faktorial $2 \times 2$. Penelitian ini menggunakan 2 kelas eksperimen yaitu kelas dengan model inquiry dan kelas problem solving.

Tabel 1. Desain Penelitian

\begin{tabular}{llll}
\hline Gaya belajar & \multicolumn{2}{l}{ Metode pembelajaran } & Total \\
\cline { 2 - 3 } & $\begin{array}{l}\text { Inquiry } \\
\text { siswa }\end{array}$ & $\begin{array}{l}\text { Problem } \\
\text { solving (B) }\end{array}$ & \\
\hline $\begin{array}{l}\text { Auditorial } \\
\text { (1) }\end{array}$ & $\mathrm{A} 1$ & $\mathrm{~B} 1$ & $(\mathrm{~A}+\mathrm{B}) 1$ \\
$\begin{array}{l}\text { Visual (2) } \\
\text { Total }\end{array}$ & $\mathrm{A} 2$ & $\mathrm{~B} 2$ & $(\mathrm{~A}+\mathrm{B}) 2$ \\
\hline
\end{tabular}

Keterangan:

$(\mathrm{A}+\mathrm{B}) 1=$ rata-rata hasil belajar siswa dari gaya belajar auditorial

$(\mathrm{A}+\mathrm{B}) 2=$ rata-rata hasil belajar siswa dari gaya belajar visual

$\mathrm{A}(1+2)=$ rata-rata hasil belajar siswa metode inquiry

$\mathrm{B}(1+2)=$ rata-rata hasil belajar siswa metode problem solving

Variabel terikat atau dependent variable dalam penelitian ini adalah hasil belajar IPS. Ada beberapa faktor yang mempengaruhi hasil belajar. Dalam penelitian ini, variabel bebas yang digunakan untuk treatment yaitu metode pembelajaran dan gaya belajar. Variabel bebas atau independent variable dalam penelitian ini yaitu metode pembelajaran. Metode pembelajaran yang digunakan untuk eksperimen yaitu inquiry dan problem solving. Variabel kontrol dalam penelitian ini yaitu gaya belajar siswa, meliputi auditorial dan visual

Hasil belajar adalah bentuk pencapaian tujuan pembelajaran yang ditandai dengan kemampuan perubahan perilaku dari individu yang berhubungan dengan kemampuan berfikir secara komprehensif ke arah yang lebih baik. Hasil belajar dalam penelitian ini adalah hasil belajar IPS secara komprehensif yang meliputi aspek pengetahuan, sikap dan keterampilan.

Inquiry adalah salah satu metode pembelajaran aktif bersifat student centered yang menekankan siswa untuk berpikir, mengkonsep, menganalisis, dengan cara menemukan sendiri pengetahuan itu, sehingga siswa dapat memahami apa yang menjadi inti pembahasan pada 
pembelajaran yang berlangsung. Cara ini mengarahkan siswa kreatif dalam mencari sumber-sumber pengetahuan yang relevan. Dalam hal ini guru tetap berperan sebagai fasilitator dan membimbing siswa dalam menemukan jawaban dari permasalahan yang ada. Kemudian siswa dapat menyimpulkan apa yang mereka peroleh dengan cara siswa sendiri. Langkahlangkah metode inquiry yaitu; menyajikan permasalahan, mengajukan hipotesis, mengumpulkan data, menguji hipotesis, menarik kesimpulan.

Metode problem solving adalah salah satu metode pembelajaran aktif yang berorientasi pada siswa untuk memecahkan masalah melalui metode ilmiah yang meliputi merumuskan masalah, mengumpulkan data, hipotesis, sampai menarik kesimpulan. Guru berperan sebagai fasilitator dan pembimbing dalam pembelajaran. Selanjutnya, siswa dituntuk untuk menemukan gagasan pemecahan masalah secara runtut dan sesuai dengan prosedur. Langkah-langkah yang dapat ditempuh untuk menerapkan metode problem solving antara lain; menyiapkan masalah yang akan dipecahkan, mencari data yang relevan, membentuk jawaban sementara, menganalisis jawaban, menarik kesimpulan.

Gaya belajar merupakan cara siswa dalam menangkap informasi atau pengetahuan yang telah menjadi kebiasaan dan diterapkan untuk mendukung proses belajar siswa. Gaya belajar siswa berbedabeda tergantung dari kebiasaan siswa. Kebiasaan itu dapat timbul dari kepribadian maupun perkembangan individu. Gaya belajar siswa dapat dibagi menjadi tiga, yaitu autiorial, visual dan kinestetik. Namun dalam penelitian ini dibatasi hanya fokus pada dua gaya belajar yaitu visual dan auditorial, karena gaya belajar kinestetik cenderung digunakan pada mata pelajaran yang menggunakan banyak gerak seperti olah raga dan seni tari.

Ada beberapa karakteristik siswa yang memiliki gaya belajar auditorial. Belajar lebih didominasi indera pendengar untuk menyerap pengetahuan yang didapat. Senang membaca dengan suara keras. Menyukai musik sebagai pendukung belajar. Mudah terganggu konsentrasi saat terdapat keributan. Lebih mudah menyampaikan sesuatu secara verbal (berbicara) daripada dengan tulisan. Memiliki kesulitan dalam memvisualisasi sesuatu. Menyukai musik atau sesuatu yang bernada dan berirama.

Karakteristik siswa yang memiliki gaya belajar visual antara lain mengandalkan indera berupa penglihatan (mata) untuk membantu proses penyerapan informasi dalam pembelajaran. Lebih mengingat apa yang dilihat daripada apa yang didengar. Tidak mudah terganggu dengan keributan. Mengutamakan penampilan. Menyukai detil sesuatu. Membaca dengan mudah dan cepat. Lebih suka membaca daripada dibacakan. Lebih suka melakukan demonstrasi daripada berpidato. Mempunyai masalah terhadap instruksi verbal dan sering meminta orang lain mengulanginya.

\section{Waktu dan Tempat Penelitian}

Penelitian ini bertempat di SMP Kota

Yogyakarta yaitu SMP Negeri 2 Yogyakarta dan SMP Negeri 9 Yogyakarta. Penelitian dilakukan pada bulan September 2015 sampai Mei 2016. Pengambilan data penelitian dilaksanakan pada semester genap bulan Januari sampai Maret 2016. Pemilihan lokasi didasarkan pada pemilihan sampel acak yang dilakukan dengan pengundian, selanjutnya memilih sekali lagi sampel dengan kriteria yang sama.

Teknik analisis data pada penelitian ini digunakan untuk menganalisis perolehan hasil belajar IPS pada siswa ditinjau dari gaya belajar. Teknik pengumpulan data dalam penelitian ini dilakukan dengan dua teknik, yaitu teknik tes dan non tes. Tes diberikan untuk mengetahui hasil belajar IPS siswa sebelum (pre-test) dan setelah mendapat perlakuan 
atau treatment penerapan metode pembelajaran sebagai hasil eksperimen (post-test). Teknik non tes berupa angket penilaian diri, penilaian keterampilan dan angket gaya belajar siswa. Angket digunakan untuk mengelompokkan siswa ke dalam aspek gaya belajar siswa auditorial, dan visual. Sedangkan penilaian diri digunakan untuk mengukur hasil belajar dari aspek sikap spiritual dan sikap sosial. Penilaian keterampilan dilakukan untuk mengukur kemampuan siswa dalam memahami materi yang ditunjukkan dalam bentuk penugasan.

Instrumen yang digunakan dalam penelitian ini yaitu instrumen tes hasil belajar IPS, instrumen penilaian sikap, dan instrumen angket gaya belajar siswa. Tujuan dari tes hasil belajar adalah untuk mengetahui pencapaian hasil belajar IPS sehingga dapat mengetahui keefektifan metode inquiry dan problem solving. Aspek penilaian dalam penelitian ini adalah penilaian pengetahuan, sikap dan keterampilan. Pada penilaian pengetahuan, tes yang digunakan yaitu pilihan ganda dengan total soal 20 butir beserta 4 alternatif jawaban.

Penilaian sikap digunakan untuk menilai mengenai sikap sosial dan spiritual siswa. Aspek sosial siswa terdiri dari aspek kerjasama dan tanggung jawab. Penilaian ini diukur dengan skala penilaian (rating scale) $1-4$ yaitu selalu (SL) $=4$ sering $(\mathrm{SR})$ $=3$ kadang-kadang $(\mathrm{KD})=2$ dan tidak pernah $(\mathrm{TP})=1$. Jika pernyataan negatif, maka penilaiannya yaitu selalu $(\mathrm{SL})=1$, sering $(\mathrm{SR})=2$, kadang-kadang $(\mathrm{KD})=3$, tidak pernah $(\mathrm{TP})=4$.

Penilaian keterampilan siswa dilakukan dengan penilaian tugas akhir siswa berupa hasil karya. Guru memberikan penugasan kepada siswa berupa tugas portofolio. Tugas tersebut mengenai analisis permasalahan sosial dan upaya pengendalian sosial disertai dengan data yang diperoleh. Setelah itu siswa diminta untuk menuangkan idenya dalam sebuah mading disertai gambar maupun kreativitas lain. Selanjutnya diberikan penilaian skor $1=$ kurang, $2=$ cukup, $3=$ baik, $4=$ sangat baik.

Instrumen angket gaya belajar siswa digunakan untuk mengetahui kecenderungan gaya belajar yang menjadi karakteristik siswa. Penilaian angket dilakukan dengan memberikan alternatif jawaban "ya" dan "tidak". Skor untuk jawaban ya $=1$, tidak $=0$. Gaya belajar siswa dihitung berdasarkan perolehan skor lebih banyak. Pernyataan untuk gaya belajar auditorial adalah butir 1-13, sedangkan pernyataan untuk gaya belajar visual adalah 14-26. Jika skor lebih banyak pernyataan angket gaya belajar auditorial, maka gaya belajar siswa adalah auditorial. Jika skor pernyataan angket gaya belajar visual lebih banyak daripada auditorial, maka gaya belajar siswa adalah visual.

\section{Validitas Instrumen}

Validitas digunakan untuk mengukur sejauh mana instrumen dapat mengukur apa yang seharusnya diukur. Instrumen penilaian hasil belajar aspek pengetahuan berupa butir soal pilihan ganda berjumlah 30 butir, angket sikap siswa aspek tanggung jawab dan kerjasama berjumlah 15 butir, sedangkan angket gaya belajar siswa berjumlah 30 butir sebelum validitas. Pada dasarnya, semua validitas instrumen menggunakan expert judgment. Uji validitas instrumen hasil belajar aspek pengetahuan menggunakan validitas isi berupa uji coba instrumen dan validitas logis. Pertama, peneliti menggunakan validitas logis yang berupa expert judgment untuk mengetahui sejauh mana instrumen soal yang digunakan telah sesuai dan dapat digunakan untuk mengukur ketercapaian tujuan/indikator pembelajaran. Setelah itu diujicobakan dan diukur dengan iteman untuk mengetahui tingkat kesukaran, daya beda dan pengecoh. Uji validitas angket gaya belajar, sikap dan keterampilan siswa menggunakan expert judgment dan diujicobakan. Selanjutnya dianalisis 
menggunakan analisis faktor yaitu principle component analysis.

Reliabilitas Instrumen

Instrumen mempunyai reliabilitas yang baik apabila dalam beberapa kali pelaksanaan pengukuran terhadap kelompok subjek yang sama diperoleh hasil yang relatif sama. Reliabilitas instrumen angket diuji menggunakan Alpha Cronbach.

Nilai reliabilitas yang diperoleh dari hasil perhitungan dengan rumus Alpha Cronbach kemudian disesuaikan $\mathrm{r}$ tabel. Menurut Rainsch (2004, p.167) jika nilai alpha $>0,7$ artinya reliabilitas telah terpenuhi. Hasil reliabilitas menunjukkan koefisien Alpha Cronbach sebesar 0,92.

\section{Teknik Analisis Data}

Teknik analisis data meliputi deskripsi data dan uji hipotesis. Deskripsi data merupakan hasil deskripsi hasil belajar pada masing-masing variabel, dilihat dari rata-rata, median, standar deviasi, nilai minimal maksimal, dan jumlah total.

Uji prasyarat analisis meliputi uji normalitas dan homogenitas. Uji normalitas digunakan untuk mengetahui apakah sampel yang digunakan untuk penelitian ini berasal dari populasi yang berdistribusi normal atau tidak. Uji homogenitas dalam penelitian ini menggunakan uji Kolmogorov-Smirnov. Hasil dikatakan normal apabila nilai signifikan $>0,05$.

Uji homogenitas digunakan untuk mengetahui apakah kedua sampel berasal dari varian yang sama. Uji homogenitas dalam penelitian ini menggunakan uji Levene. Data dikatakan memiliki homogenitas apabila nilai signifikan $>0,05$.

Pengujian hipotesis menggunakan analisis varian (anava) 2x2. Uji analisis varian digunakan untuk mengetahui perbedaan hasil belajar pada metode inquiry dan problem solving, selain itu juga dilihat perbedaan pada variabel moderat yaitu gaya belajar siswa. Untuk menjawab hiptesis 2 dan 3 digunakan uji-t independent. Hasil uji analisis dikatakan memiliki perbedaan yang signifikan apabila memiliki nilai signifikansi apabila nilai signifikansi $\leq 0,05$.

\section{Hasil Penelitian dan Pembahasan}

Hasil belajar IPS meliputi aspek pengetahuan, sikap dan keterampilan. Hasil belajar IPS tersebut disebut komprehensif karena penggabungan antara ketiga aspek yaitu pengetahuan, sikap dan keterampilan. secara lebih jelas, data hasil belajar secara komprehensif dapat dilihat pada tabel 2.

Tabel 2. Data Statistik Hasil Belajar IPS secara Komprehensif pada Kelas Inquiry dan Problem

\begin{tabular}{|c|c|c|}
\hline Deskripsi & Inquiry & $\begin{array}{c}\text { Problem } \\
\text { solving }\end{array}$ \\
\hline Mean & 78,38 & 82,24 \\
\hline Median & 77,78 & 81,25 \\
\hline Std. Deviation & 4,56 & 5,51 \\
\hline Minimum & 68,89 & 66,67 \\
\hline Maximum & 86,94 & 92,78 \\
\hline Sum & 2429,71 & 2796,10 \\
\hline
\end{tabular}

belajar IPS secara komprehensif yaitu 78,38 median yaitu 77,78 , standar deviasi 4,56 nilai minimum 68,89 nilai maksimum 86,94 . Pada kelas problem solving rata-rata hasil belajar IPS secara komprehensif yaitu 82,24 median 81,25 standar deviasi 5,51 nilai minimal 66,67 nilai maksimal 92,78 . Berdasarkan data tersebut, kelas problem solving memiliki rata-rata hasil belajar IPS secara komprehensif lebih tinggi daripada kelas inquiry.

Hasil belajar IPS secara komprehensif yang meliputi aspek pengetahuan sikap dan keterampilan juga dilihat berdasarkan gaya belajar siswa. Gaya belajar yang dilibatkan dalam penelitian ini ada dua yaitu auditorial dan visual. Tabel 3 menunjukkan hasil belajar IPS siswa dilihat dari masing-masing gaya 
belajar. Secara lebih jelas, dapat dilihat pada tabel 3 .

Tabel 3. Distribusi Hasil Belajar IPS secara Komprehensif Berdasarkan Gaya Belajar

\begin{tabular}{|c|c|c|c|c|}
\hline \multirow[b]{2}{*}{ Deskripsi } & \multicolumn{2}{|c|}{ Auditorial } & \multicolumn{2}{|c|}{ Visual } \\
\hline & inquiry & $\begin{array}{c}\text { problem } \\
\text { solving }\end{array}$ & inquiry & $\begin{array}{c}\text { problem } \\
\text { solving }\end{array}$ \\
\hline Mean & 78,44 & 78,05 & 78,29 & 85,54 \\
\hline Median & 78,06 & 79,72 & 77,50 & 86,11 \\
\hline $\begin{array}{l}\text { Std. } \\
\text { deviasi }\end{array}$ & 5,07 & 4,12 & 3,82 & 4,04 \\
\hline Minimum & 68,89 & 66,67 & 71,94 & 78,06 \\
\hline Maximum & 86,11 & 81,94 & 86,94 & 92,78 \\
\hline Sum & 1490,29 & 1170,82 & 939,42 & 1625,28 \\
\hline
\end{tabular}

Tabel 3 menunjukkan bahwa pada gaya belajar auditorial, rata-rata hasil belajar IPS secara komprehensif pada kelas inquiry yaitu 78,44 median 78,06 standar deviasi 5,07 sedangkan pada kelas problem solving, rata-rata yaitu 78,05 median 79,72 standar deviasi 4,12. Hal ini dapat disimpulkan bahwa pada siswa dengan gaya belajar auditorial, siswa yang belajar menggunakan metode inquiry memperoleh hasil belajar lebih tinggi daripada problem solving. Pada siswa dengan gaya belajar visual, hasil belajar IPS secara komprehensif kelas inquiry memiliki ratarata 78,29 median 77,50 standar deviasi 3,82 sedangkan pada kelas problem solving, rata-rata yaitu 85,54 median 86,11 standar deviasi 4,04. Hal ini dapat disimpulakan bahwa siswa dengan gaya belajar visual memiliki hasil belajar lebih tinggi pada kelas problem solving daripada inquiry.

Setelah melakukan deskripsi data, selanjutnya data tersebut diuji untuk menjawab rumusan masalah. Sebelum melakukan uji hipotesis, data harus memenuhi asumsi prasyarat analisis. Uji prasyarat analisis pada uji anava $2 \times 2$ yaitu normalitas dan homogenitas.

Uji normalitas dalam penelitian ini menggunakan uji Kolmogorov Smirnov.
Pengujian dikatakan memenuhi syarat apabila nilai signifikansi sebesar $>0,05$. Apabila memenuhi persyaratan, maka data berdistribusi normal.

Berdasarkan hasil uji normalitas, seluruh variabel dinyatakan normal. Sesuai dengan asumsi bahwa data dikatakan normal jika nilai signifikansi $>0,05$. Hasil uji normalitas hasil belajar IPS secara komprehensif metode inquiry yaitu 0,994 > 0,05 . Hasil uji normalitas hasil belajar komprehensif metode problem solving yaitu $0,888>0,05$ Hasil uji normalitas hasil belajar gaya belajar auditorial pada metode inquiry yaitu $0,998>0,05$. Hasil uji normalitas hasil belajar gaya belajar auditorial pada metode problem solving yaitu 0,396 > 0,05. Hasil uji normalitas hasil belajar gaya belajar visual pada metode inquiry yaitu $0,980>0,05$. Hasil uji normalitas hasil belajar gaya belajar visual pada metode problem solving yaitu $0,965>$ 0,05 .

Berdasarkan analisis tersebut, maka semua pengelompokan sampel dalam penelitian ini berasal dari populasi yang terdistribusi normal karena nilai signifikansinya lebih dari 0,05 . Langkah selanjutnya yaitu dengan uji homogenitas.

Uji homogenitas dalam penelitian ini menggunakan uji Levene test. Pengujian dikatakan memenuhi syarat apabila nilai signifikansi sebesar $>0,05$. Apabila memenuhi persyaratan, maka data adalah homogen.

Berdasarkan hasil uji homogenitas, seluruh variabel dinyatakan homogen. Sesuai dengan asumsi bahwa data dikatakan homogen jika nilai signifikansi > 0,05 . Hasil uji homogenitas hasil belajar IPS secara komprehensif yaitu $0,378>$ 0,05 . Hasil uji homogenitas hasil belajar gaya belajar auditorial yaitu $0,281>0,05$. Hasil uji homogenitas hasil belajar gaya belajar visual yaitu $0,810>0,05$.

Setelah uji asumsi terpenuhi, selanjutnya dapat dilakukan uji hipotesis. Uji hipotesis dalam penelitian ini menggunakan analisis varian $2 \times 2$. 
Hipotesis ini digunakan untuk menguji perbedaan dua kelompok yang mana dua kelompok tersebut masih memiliki varian pembeda.

Hasil uji hipotesis pertama menunjukkan bahwa terdapat pengaruh yang signifikan metode inquiry dan problem solving terhadap hasil belajar IPS secara komprehensif di SMP Kota Yogyakarta dengan nilai signifikansi 0,003 $<0,05$ maka dapat disimpulkan bahwa terdapat perbedaan yang signifikan hasil belajar siswa antara metode inquiry dan problem solving.

IPS merupakan salah satu mata pelajaran yang diajarkan di tingkat SMP. Tujuannya adalah agar peserta didik mampu menelaah dan memecahkan fenomena sosial yang ada di masyarakat. Metode yang prinsipnya menekankan pada pemecahan masalah adalah problem solving dan inquiry. Selain itu metode ini juga mengacu pada pembelajaran berbasis saintifik. Oleh karena itu, pembelajaran sebaiknya diarahkan pada pemecahan masalah dengan menggunakan metode inquiry dan problem solving agar tujuan pembelajaran IPS dapat tercapai.

Penelitian yang dilakukan yaitu membandingkan perbedaan yang signifikan antara metode inquiry dan problem solving. jika kedua metode tersebut memiliki hasil yang tinggi, maka metode tersebut dikatakan efektif. Keefektifan pembelajaran salah satunya dilihat dari hasil belajar. Jika hasilnya baik, maka pembelajaran dapat dikatakan efektif. Inquiry merupakan metode yang berbasis ilmiah karena dalam langkah-langkahnya bersifat menemukan dengan metode ilmiah. Metode problem solving merupakan metode yang mengarahkan pada pemecahan masalah.

Perbedaan metode inquiry dan problem solving yaitu, pada metode inquiry, siswa sendiri yang menemukan konsep dan menemukan permasalahan dianalisis, sedangkan pada metode problem solving, konsep telah diketahui terlebih dulu dengan pembelajaran oleh guru, selanjutnya siswa hanya perlu menemukan permasalahan yang selanjutnya ditelaah dan dianalisis menggunakan langkahlangkah problem solving. Fokusnya adalah pada analisis pemecahan masalah, bagaimana siswa dapat menemukan kreativitas pemecahan masalah sesuai dengan materi yang diajarkan. Hasil menunjukkan bahwa terdapat perbedaan yang signifikan antara metode inquiry dan problem solving.

Pada aspek pengetahuan, metode problem solving memiliki rata-rata gain score lebih tinggi yaitu sebesar 28,24 lebih besar daripada inquiry yaitu 22,58. Hal ini berarti metode problem solving lebih efektif dalam meningkatkan hasil belajar daripada metode inquiry. Pada metode problem solving, siswa telah mengetahui konsep awal dengan belajar antara guru dengan siswa, kemudian siswa dihadapkan pada suatu permasalah kontekstual sesuai dengan materi yang diajarkan, mencari sebuah permasalahan yang ada pada materi pembelajaran, kemudian menemukan solusi yang ditawarkan. Adanya solusi menjadikan siswa paham akan pemecahan masalah sehingga kemampuan berpikir siswa lebih tinggi.

Pada metode inquiry, memiliki hasil lebih rendah dibandingkan dengan metode problem solving karena pada awal, siswa sendiri yang harus menemukan konsep sendiri sesuai dengan kelompok belajarnya - Seperti pendapat Abdul Majid (2013, pp.227-228) bahwa inquiry sulit diimplementasikan apabila pembelajaran ditentukan oleh kemampuan siswa. Langkah ini merupakan langkah yang sedikit sulit untuk diterapkan pada siswa dalam tingkat SMP karena siswa masih pada masa transisi berpikir ke arah yang lebih tinggi. Metode ini juga lebih cocok diterapkan pada siswa yang memiliki kemampuan cukup. Dilihat dari segii langkah-langkah pembelajaran, inquiry memiliki langkah-langkah yang lebih 
banyak dan lebih sulit daripada problem solving. Oleh karena itu, langkah-langkah yang lebih banyak dan lebih sulit ini mempengaruhi hasil belajar. Namun pada dasarnya, kedua metode baik inquiry maupun problem solving telah berhasil dalam meningkatkan hasil belajar siswa. Terbukti dengan nilai rata-rata dengan kategori baik

Hasil belajar terdiri dari 3 aspek yaitu pengetahuan, sikap dan keterampilan. Jadi pembelajaran tidak selalu berwujud pengetahuan saja, namun juga sikap dan keterampilan. Artinya, dengan belajar siswa mampu menguasai konsep dan pengetahuan, memiliki sikap yang baik sehingga dalam bergaul maupun bersosialisasi dalam lingkungan, siswa mampu menjadi pribadi yang baik, berakhlak mulia dan berkarakter, memiliki keterampilan artinya siswa mampu untuk mengembangkan potensi atau keahlian yang dimiliki untuk bekal hidup ke depannya.

Aspek sikap merupakan penilaian hasil belajar yang harus dilakukan untuk mengetahui ketercapaian perilaku siswa yang diharapkan, diantaranya adalah aspek spiritual dan aspek sosial. Aspek spiritual memasukkan nilai-nilai religius yang terkandung bagaimana siswa berhubungan dengan Tuhan maupun sesama manusia. Aspek sikap sosial meliputi tanggung jawab dan kerjasama diharapkan dapat diterapkan dalam kegiatan pembelajaran maupun di luar pembelajaran dalam rangka membentuk akhlak terpuji. Oleh karena itu, pada dasarnya belajar tidak hanya berubah dalam aspek pengetahuan saja, namun juga berubah dalam tingkah-laku atau sikap ke arah yang lebih baik. Berdasarkan hasil belajar aspek sikap, rata-rata sikap menunjukkan bahwa metode inquiry memiliki rata-rata sebesar 47,84 dan metode problem solving memiliki rata-rata sebesar 50,18 dari nilai maksimal 60 .

Hasil belajar selanjutnya adalah aspek keterampilan. Keterampilan yang dimaksud dalam penelitian ini adalah keterampilan pemahaman materi yang terwujud dalam pemecahan masalah, dan dituangkan melalui pembuatan mading. Selain keterampilan pemecahan masalah, siswa juga diberikan kebebasan dalam berkreativitas membuat karya sesuai dengan ilustrasi permasalahan yang diangkat. Hasil belajar aspek keterampilan menunjukkan bahwa rata-rata kelas problem solving lebih besar yaitu 16,41 sedangkan kelas inquiry sebesar 15,79 dari nilai maksimal 20. Penilaian keterampilan yang dilakukan adalah menentukan analisis masalah serta keterampilan dalam menuangkannya ke dalam mading serta presentasi

Hasil uji hipotesis kedua menunjukkan bahwa tidak terdapat pengaruh yang signifikan metode inquiry dan problem solving terhadap hasil belajar IPS secara komprehensif pada gaya belajar auditorial. Nilai signifikansi yaitu $0,815>0,05$ maka dapat disimpulkan bahwa tidak terdapat perbedaan yang signifikan hasil belajar siswa pada gaya belajar auditorial antara siswa yang belajar menggunakan metode inquiry dan problem solving.

Hasil belajar menunjukkan bahwa tidak terdapat perbedaan yang signifikan hasil belajar siswa pada gaya belajar auditorial antara siswa yang belajar menggunakan metode inquiry dan problem solving. Namun jika dilihat dari nilai ratarata menunjukkan bahwa pada siswa yang memiliki gaya belajar auditorial, hasil belajar siswa dengan metode inquiry memiliki nilai rata-rata sedikit lebih tinggi daripada hasil belajar siswa siswa yang belajar dengan metode problem solving yaitu 78,44 > 78,05. Uji hipotesis tidak menunjukkan hasil yang signifikan karena pada dasarnya, kedua metode, baik itu inquiry maupun problem solving keduanya memiliki karakteristik untuk memaksimalkan pendengaran seperti ceramah dan diskusi. Jadi, karena kedua metode memiliki persamaan dalam implementasinya, maka hasilnya tidak 
terdapat perbedaan yang signifikan hasil belajar inquiry dan problem solving pada gaya belajar auditorial.

Hasil uji hipotesis ketiga menunjukkan bahwa terdapat perbedaan pengaruh yang signifikan metode inquiry dan problem solving terhadap hasil belajar IPS secara komprehensif pada gaya belajar visual. nilai signifikansi yaitu $0,000<0,05$ maka dapat disimpulkan bahwa terdapat perbedaan yang signifikan hasil belajar siswa pada gaya belajar visual antara siswa yang belajar menggunakan metode inquiry dan problem solving.

Hasil belajar menunjukkan terdapat perbedaan yang signifikan hasil belajar siswa pada gaya belajar visual antara siswa yang belajar menggunakan metode inquiry dan problem solving. Hal ini juga didukung dengan nilai rata-rata hasil belajar pada siswa yang memiliki gaya belajar visual, siswa dengan metode problem solving memiliki nilai rata-rata lebih tinggi daripada hasil belajar siswa siswa dengan metode inquiry. Hasil belajar pada siswa pada metode problem solving memiliki hasil yang lebih tinggi daripada inquiry. Hal ini terjadi karena dalam metode problem solving, pembelajaran lebih banyak melibatkan visualisasi, melihat video, gambar, maupun artikel mengenai permasalahan yang terjadi pada konteks masyarakat sosial karena sesuai dengan materi pokok yang diajarkan yaitu pengendalian penyimpangan. namun juga terdapat diskusi dan penyampaian pendapat dari teman. Hasil penelitian ini juga didukung dengan penelitian sebelumnya oleh Utami $(2015$, p.7) yang menunjukkan bahwa pada metode Problem Based Learning (PBL) siswa dengan gaya belajar visual memiliki hasil belajar lebih tinggi daripada metode TPS.

Berdasarkan pembahasan ini, metode problem solving memiliki hasil belajar yang lebih tinggi daripada metode inquiry yaitu 85,54 > 78,29. Karena metode memiliki karakteristik tertentu dalam implementasinya, jadi jika suatu metode lebih banyak melibatkan visualisasi dalam pembelajaran, maka akan lebih cocok digunakan pada siswa yang memiliki gaya belajar visual. Sebaliknya, jika karakteristik suatu metode lebih banyak melibatkan pendengaran seperti ceramah dan diskusi, maka akan lebih cocok digunakan untuk siswa yang memiliki gaya belajar auditorial.

Hasil uji hipotesis keempat menunjukkan bahwa terdapat interaksi pengaruh metode pembelajaran dan gaya belajar terhadap hasil belajar IPS secara komprehensif di SMP Kota Yogyakarta. Hasil uji hipotesis menunjukkan bahwa terdapat interaksi pengaruh antara metode pembelajaran dan gaya belajar. Hal ini dilihat berdasarkan nilai signifikansi 0,001 $<0,05$ dan hasil kurva antara metode pembelajaran dan gaya belajar berpotongan.

Hasil belajar, yaitu faktor eksternal adalah penggunaan metode pembelajaran dan faktor internal yaitu karakteristik siswa atau bisa disebut dengan gaya belajar. Perbedaan hasil belajar IPS siswa dengan menggunakan metode inquiry dan problem solving ternyata menunjukkan nilai signifikan. Kedua metode tersebut juga dapat mempengaruhi hasil belajar karena terbukti mencapai ketuntasan. Metode problem solving mempunyai hasil rata-rata lebih tinggi daripada inquiry. Penelitian ini juga melihat adakah pengaruh gaya belajar terhadap hasil belajar. Setelah dilakukan uji hipotesis, terdapat perbedaan yang signifikan.

Pada dasarnya, tidak ada gaya belajar yang lebih baik karena gaya belajar siswa baik itu auditorial maupun visual memiliki kelemahan dan kelebihan dalam menyerap informasi. Hanya saja, siswa harus bisa menyesuaikan kelemahan gaya belajar yang mereka miliki agar dapat menyesuaikan dengan metode pembelajaran yang digunakan. Selain itu, guru harus bisa memilih metode yang 
cocok untuk siswa berdasarkan karakteristik/gaya belajar. Hal ini sesuai dengan jurnal yang ditulis oleh O'Leary \& Stewart (2013, p.1) yaitu "Instructors should consider learning styles before deciding on appropriate teaching methods". Selain itu pendapat Ismail (2008, p.31) menyatakan bahwa "kualitas pembelajaran ditentukan oleh kualitas pengujian, penjelasan, dan pengaturan unsur-unsur belajar dengan memperhatikan metode-metode pembelajaran dan efektivitasnya sesuai dengan kebutuhan dan karakteristik siswa secara individual." Pendapat tersebut telah mewakili bahwa hasil belajar dapat dipengaruhi oleh penggunaan metode pembelajar, dan juga karakteristik siswa. Karakteristik siswa dapat dijabarkan sebagai gaya belajar siswa. Hasilnya, pada gaya belajar auditorial, siswa yang belajar menggunakan metode inquiry lebih tinggi daripada siswa yang belajar dengan metode problem solving. Pada gaya belajar visual, siswa yang belajar menggunakan metode problem solving lebih tinggi daripada siswa yang belajar dengan metode inquiry. Jadi dapat disimpulkan bahwa terdapat interaksi antara metode pembelajaran dan gaya belajar siswa terhadap hasil belajar.

\section{Simpulan, Implikasi dan Saran}

Simpulan

Terdapat perbedaan pengaruh yang signifikan metode inquiry dan problem solving terhadap hasil belajar IPS secara komprehensif di SMP Kota Yogyakarta . Terdapat perbedaan pengaruh yang signifikan hasil belajar siswa aspek pengetahuan antara metode inquiry dan problem solving dengan nilai signifikansi $0,003<0,05$. Rata-rata hasil belajar metode inquiry dan problem solving berada pada kategori baik dan sangat baik yaitu 78,36 dan 81,79 . Metode problem solving lebih efektif dalam meningkatkan hasil belajar aspek pengetahuan daripada metode inquiry karena nilai rata-rata kelas problem solving lebih tinggi daripada metode inquiry.

Tidak terdapat perbedaan pengaruh yang signifikan metode inquiry dan problem solving terhadap hasil belajar IPS secara komprehensif pada gaya belajar auditorial dengan nilai signifikansi $0,815>$ 0,05. Hasil belajar menunjukkan bahwa tidak terdapat perbedaan yang signifikan hasil belajar siswa pada gaya belajar auditorial antara siswa yang belajar menggunakan metode inquiry dan problem solving. Hal ini dikarenakan pada pelaksanaannya, kedua metode memiliki persamaan dalam memaksimalkan pendengaran yaitu terdapat ceramah dan diskusi.

Terdapat perbedaan pengaruh yang signifikan metode inquiry dan problem solving terhadap hasil belajar IPS secara komprehensif pada gaya belajar visual dengan nilai signifikansi $0,001<0,05$. Hasil belajar menunjukkan terdapat perbedaan yang signifikan hasil belajar siswa pada gaya belajar visual antara siswa yang belajar menggunakan metode inquiry dan problem solving. Metode problem solving lebih cocok untuk siswa dengan gaya belajar visual karena nilai rata-rata siswa visual lebih tinggi daripada auditorial.

Terdapat interaksi pengaruh metode pembelajaran dan gaya belajar terhadap hasil belajar IPS secara komprehensif di SMP Kota Yogyakarta. Hasil menunjukkan bahwa terdapat pengaruh yang signifikan antara metode pembelajaran dan gaya belajar terhadap hasil belajar dengan nilai signifikansi $0,001<0,05$. Berdasarkan hal tersebut, maka dapat disimpulkan bahwa terdapat pengaruh interaksi metode dan gaya belajar terhadap hasil belajar. Metode problem solving lebih cocok dengan siswa yang memiliki gaya belajar visual.

Implikasi

Metode berpengaruh terhadap hasil belajar. Metode yang lebih efektif dalam meningkatkan hasil belajar siswa adalah 
metode problem solving. Oleh karena itu, apabila guru menerapkan metode problem solving dalam pembelajaran IPS pada materi pranata dan pengendalian penyimpangan sosial, maka siswa akan mencapai ketuntasan hasil belajar aspek pengetahuan.

Tidak terdapat perbedaan hasil belajar metode inquiry dan problem solving pada gaya belajar auditorial. Karena pada prinsipnya menggunakan pendengaran dalam menangkap pembelajaran. Namun kedua metode mampu meningkatkan hasil belajar pada siswa auditorial karena hasil belajar mencapai ketuntasan.

Hasil belajar pada gaya belajar visual lebih tinggi dengan problem solving daripada inquiry. Oleh karena itu apabila guru menerapkan metode problem solving dalam pembelajaran IPS dengan materi pranata dan pengendalian penyimpangan sosial pada siswa yang memiliki gaya belajar visual, maka hasil belajar akan mencapai ketuntasan. Apabila siswa lebih dominan memiliki gaya belajar visual, maka guru sebaiknya menerapkan metode problem solving.

Hasil penelitian menunjukkan bahwa terdapat interaksi pengaruh antara metode pembelajaran dan gaya belajar siswa terhadap hasil belajar. Oleh karena itu, dalam menerapkan pembelajaran di kelas, apabila guru mampu memilih metode yang baik sesuai dengan gaya belajar siswa, maka hasil belajar siswa akan mencapai ketuntasan.

\section{Saran}

Pelaksanaan pembelajaran sebaiknya memperhatikan penerapan metode pembelajaran, karena pemilihan metode pembelajaran dapat mempengaruhi hasil belajar.

Apabila dalam pelaksanaan pembelajaran ssiwa lebih dominan dengan

Kemendikbud. (2014). Lampiran Peraturan Menteri Pendidikan dan Kebudayaan Republik Indonesia Nomor 104 Tahun 2014 tentang gaya belajar auditorial, guru dapat menerapkan metode inquiry maupun problem solving karena kedua metode tersebut memaksimalkman pendengaran.

Apabila dalam pelaksanaan pembelajaran siswa lebih dominan dengan gaya belajar visual, guru sebaiknya menerapkan metode problem solving.

Dalam proses pembelajaran, guru sebaiknya memperhatikan metode yang cocok diterapkan dalam pembelajaran dengan disesuaikan dengan gaya belajar siswa, karena metode dan gaya belajar berpengaruh terhadap hasil belajar.

\section{Daftar Pustaka}

Bloom, B.S. (1956). Taxonomy of educational objectives.: the classification of education goals. London: Longman Group LTD.

Burden, P.R. \& Byrd, D.M. (2011). Methods for effective teaching: meeting the needs of all students $6^{\text {th }}$ edition. New York: Pearson.

Flick, L.B. \& Lederman, L.B. (2006). Scientific inquiry and nature of science: implications for teaching, learning and teacher education. New York: Springer.

Hosman, M. (2014). Pendekatan saintifik dan kontekstual dalam pembelajaran abad 21. Jakarta: Ghalia Indonesia.

Ismail. (2008). Strategi pembelajaran agama islam berbasis PAIKEM pembelajaran aktif, inovatif, kreatif, efektif, dan menyenangkan. Semarang: Rasail.

Kemendikbud. (2013). Lampiran Peraturan Menteri Pendidikan dan Kebudayaan Republik Indonesia Nomor 66 Tahun 2013 tentang Standar Penilaian Pendidikan.

Penilaian Hasil Belajar oleh Pendidik pada Pendidikan Dasar dan Pendidikan Menengah. 
Kilbane, C.R. \& Milman, N.B. (2014). Teaching models designing instruction for $21^{\text {st }}$ century learners. New York: Pearson.

Majid, A. (2013). Strategi pembelajaran. Bandung: Remaja Rosdakarya.

Majid, A. (2014). Pembelajaran tematik terpadu. Bandung: Remaja Rosdakarya.

O'Leary, C. \& Stewart, J. (2013). The interaction of learning style and teaching methodologies in accounting ethical instruction. Journal of Business Ethics, 113(2), 225 - 241.

Rainsch, S. (2004). Dynamic strategic analysis: demystifying simple success strategies. Wiesbaden: Deutscher Universitasts-Verlag.

Sanjaya, W. (2006). Proses belajar mengajar berorientasi standar proses. Jakarta: Kencana Prenada Media Grup.

Shoimin, A. (2014). 68 model pembelajaran inovatif dalam kurikulum 2013. Yogyakarta: Ar-Ruzz Media.

Supardi. (2011). Dasar-dasar ilmu sosial. Yogyakarta: Ombak.

Utami, P., \& Gafur, A. (2015). Pengaruh metode pembelajaran dan gaya belajar siswa terhadap hasil belajar IPS di SMP negeri di kota Yogyakarta. Harmoni Sosial: Jurnal Pendidikan IPS, 2(1), 97-103. Retrieved from http://journal.uny.ac.id/index.php/hsjpi /article/view/4622

\section{Profil Singkat}

Azharotunnafi, S.Pd. menempuh SD dan SMP di Kulonprogo, alumni SMA N 5 Yogyakarta. Mahasiswa lulusan S1 prodi Pendidikan IPS UNY. Lahir di Kulonprogo, 18 Juni 1991. Aktivis kampus pada tahun 2010-2012 sebagai staf infokom dan bendahara UKMF Penelitian SCREEN FIS UNY. Selain di kampus juga aktif di desa sebagai ketua Karangtaruna Desa Kaligintung. 